\title{
Customer Relationship Management (CRM) Technology and Organization Performance: Is Marketing Capability a Missing Link? An Empirical Study in the Malaysian Hotel Industry
}

\author{
Abdul Alem Mohammed ${ }^{1}$, Basri B. Rashid ${ }^{1} \&$ Shaharuddin B. Tahir ${ }^{1}$ \\ ${ }^{1}$ School of Tourism, Hospitality and Environmental Management, Univerisiti Utara Malaysia, Sintok, Malaysia \\ Correspondence: Abdul Alem Mohammed, School of Tourism, Hospitality and Environmental Management, \\ Univerisiti Utara Malaysia, Sintok, Malaysia. E-mail: m.abdulalem@yahoo.com
}

Received: January 29, 2014

doi:10.5539/ass.v10n9p197
Accepted: March 20, 2014 Online Published: April 29, 2014

URL: http://dx.doi.org/10.5539/ass.v10n9p197

\begin{abstract}
Due to the aggressive market competition in hotel sector, it is critical that hotels should adopt new strategy like CRM technology to assist hotel employees, serve customers better and improve organization performance. However, prior studies indicated that the relationship between CRM technology and organization performance is equivocal. These mixed results may be to a lack of understanding of the mechanisms that link CRM technology and organization performance. For this reason, the study used marketing capabilities (planning and implementation) as mediators between CRM technology and organization performance. The study surveyed a sample of 447 hotels firm in Malaysia and used correlation and regression for analyses and testing. The findings suggest that CRM technology is associated with the four dimensions of organization performance (i.e. financial, customer, internal process and learning and growth). In addition the findings reveal that marketing capabilities (planning and implementation) play a mediator role in the relationship between CRM technology and various dimensions of organization performance.
\end{abstract}

Keywords: CRM, marketing planning capability, marketing implementation capability, hotel performance

\section{Introduction}

With current advance of information technology, a new system can be used to enhance the power of organization toward reduction of internal costs, better relationship with the environment, which may consequently lead to economic profit in the long run. In this regard, it has been shown that different classes of hotels implement different Customer Relationship Management (CRM) systems (Moriarty-Jones, Rowley \& Kupiec-Teahan, 2008).

In recent times, one of the most important strategies in hotel industry is how can hotels use their technology resources in marketing because it enables organizations to make the right decision based on the right information that collected from the right customers (Dev \& Olsen, 2000). Thus, CRM technology is supposed to improve an organization's ability to maintain profitable customer relationships through facilitating integration and sharing information that is capable of influencing smooth and efficient organization-customer interactions, effective analysis of customer data, personalize and customize their products and services (Mukerjee \& Singh, 2009).

Even though CRM technology has been linked to organizational performance, there is a lack of empirical research that investigates the relationship of CRM technology and various dimensions of hotel performance (Fan $\& \mathrm{Ku}, 2010 ; \mathrm{Wu} \& \mathrm{Lu}, 2012)$. Therefore, $\mathrm{CRM}$ is bound to constantly receive attention for future research in hospitality industry. Specifically, it was contended that there is research opportunity regarding hospitality industry, and thus scholars can contribute to theory development in that direction (Yoo, Lee \& Bai, 2011; Line \& Runyan, 2012).

As additional justification for future research regarding CRM technology and organization performance, past studies have showed inconsistent results regarding their relationship. Specifically, some of the past studies demonstrated a significant and positive effect CRM technology on organization performance (Akroush et al., 2011; Kasim \& Minai, 2009), while others have reported non-significant association between CRM technology and organization performance (Ernst, Hoyer, Krafft, \& Krieger, 2011; Jayachandran et al., 2005; Reigby, 2004; Yim et al., 2004). Furthermore, some studies demonstrated that CRM technology only had an indirect significant 
effect on organization performance through organizational factors (Garrido-Moreno \& Padilla-Melendez, 2011). These mixed findings might have been a result of lack of understanding of the mechanisms that link CRM with organizational performance (Ernst et al., 2011; Reimann, Schilke, \& Thomas, 2010). Consequently, further mediation research was suggested as crucial for assessing the role and impact of CRM technology in affecting organization performance (Ernst et al., 2011; Chang et al., 2010).

In response to the call for mediation research, Chang, Park, and Chaiy (2010) examined the mediating effect of marketing capabilities on the relationship between CRM technology and organization performance. Their finding showed that marketing capabilities including planning and implementation played mediating roles on the relationship between CRM technology and organization performance. However, they did not examine the effect of marketing capabilities including planning and implementation separately, and they also suggested future studies to investigate the two types of marketing capabilities (i.e. planning and implementation) individually. Additionally, their study overlooked to assess the influence of CRM technology on dimensions of organization performance (i.e. financial performance, customer performance, internal process performance, and learning and growth performance).

Importantly, previous studies that examined the effect of information technology on organization performance in developing countries, specifically in Asia are limited. Thus, there is the need for more studies to be conducted within the hotel industry in Asian countries (Siriak, Islam \& Khang, 2011). In this respect, Malaysia has been recording a steady growth in the tourist industry. Statistics indicate a threefold increase of tourist expenditure from 2006-2012; tourist arrivals have increased from 17.55 million in 2006 to 25.03 million in 2012, with receipts of RM 60.6 billion (Tourism Malaysia, 2013). However, the statistics for the average occupancy rate for hotels in Malaysia indicated that the percentage fluctuated and moderated between 2006 and 2012 (Tourism Malaysia, 2013). Furthermore, Kasim and Minai (2009) contended that there is a low usage of information technology amongst the hotels in Malaysia which can lead to lower quality decision-making and consequently can influence hotels performance adversely. Therefore, hotels must implement suitable strategies to face the strong competition in the market and consequently improve their performance, increase occupancy rates and achieve profit (Yen \& Othman, 2011). Additionally, there are few studies of CRM on hotel performance in the Malaysia context, and there is a need for more research in this area (Kasim \& Minai, 2009). Therefore it is important to investigate how the hotel industry's performance can be improved. In this case, Sigala (2005) asserted that CRM as a competitive advantage strategy becomes a necessity for attracting and improving guests' patronage in the hotel industry.

Against this background, the current study addressed the following objectives: 1) to investigate the effect of CRM technology on various dimensions of hotel performance (i.e. financial, customer, internal business process, and learning and growth perspective). (2) To investigate the mediating effects of marketing capabilities (planning and implementation) on the relationship between CRM technology and hotel performance dimensions.

This study is organized in to four sections as follows: (1) review discussion of study variables and statements of the study hypotheses; (2) discussion of the methodology adopted for this study; (3) presentation of results and discussion of findings; (4) presentation of conclusions, limitations and recommendations.

\section{Literature Review}

\subsection{CRM Technology}

CRM technology include all computer technologies that are used by organizations to build long term and strong relationship with their customers (Sin, Alan, \& Yim, 2005; Yim et al., 2004; Garrido-Moreno \& Padilla-Melendez, 2011). In view of this, Rigby, Reichheld, and Schefter (2002) argued that CRM technology is information technology-based solutions designed to support the customer relationship management process.

The computer technologies required in CRM include front-office applications supporting sales, marketing and service; and back-office applications facilitating the integration and analysis of data (Greenberg, 2001; Jayachandran, Sharma, Kaufman, \& Raman, 2005).

The CRM front-office components enable the smooth transfer of information from the organization to customers by routing the information to relevant employees working in relevant units including marketing, sales, and service. In other words, CRM implementation allows the smooth passage of customer knowledge within an organization that could lead enhanced decision making (Ryals, 2005).

On the other hand, the back office components like the database and data-mining tools assist in identifying and tracking customer needs effectively and efficiently. The creation of a database of centralized customer information is an important element of CRM activities. CRM's data mining tools help improve the firms' 
understanding of customer behaviour and allows for tailor-made products and service.

\subsection{Measuring Hotel Performance}

It is believed that organizations have to measure their performance in order to determine the effectiveness of organizational strategies. In this case, researches on firm performance utilized different methods to measure and conceptualize performance. It has been argued that organization performance is a multi-dimensional concept that cannot be sufficiently reflected in a single performance dimension (Randolph \& Dess, 1984).

Kaplan and Norton (1992) argued that financial management alone is not sufficient in assessing an organization's competitive position; hence, they proposed a comprehensive model called the "Balanced Scorecard" (BSC). BSC attempts to provide a more balanced performance measurement for organizations. BSC model includes both financial and three other non-financial measures including customers, internal process and learning and growth. Kaplan and Norton (1992) mentioned that the balanced scorecard consists of four dimensions including financial perspective, customer perspective, internal process perspective, and learning and growth/innovation perspective.

It has been argued that BSC can provide a deeper understanding of business performance because it does not only includes traditional financial approach to assess tangible assets, but also uses non-financial approaches to assess intangible assets or intellectual property (Wu \& Lu, 2012). In addition, financial dimension cannot alone give a complete understanding of CRM effects, and therefore, the overall performance that involve financial and non financial dimensions are used in the assessment of CRM outcomes (Wu \& Hung, 2007). Therefore, using balance score card to assess the influence of CRM on organization performance becomes relevant because it is a useful technique for evaluating an organization's overall operational performance (Wu \& Hung, 2007; Wu \& Lu, 2012). Therefore, this study used the four dimensions of BSC approach (financial, customer, internal process and learning and growth) to measure hotel performance.

\subsection{CRM Technology and Organization Performance}

Previous studies demonstrated that not all organizations can get the same benefits of CRM technology, however, hotel industry is seen as a good context to implement CRM model because it possesses enough information regarding customers and their various needs and it can utilize this important resource to build an effective customer relationship (Kotler, 2002; Piccoli et al., 2003). Consistent with this thinking, Kasim and Minai (2009) argued that hotels can use information technology to improve their performance. Additionally, Minghetti (2003) asserted that CRM policy development calls for an in-depth knowledge of customers' needs, behavior, and preferences, and those new technologies are one of the core drivers of change.

Similarly, Law, Leung and Buhalis (2009) argued that in the today's era of internet, e-mail inquiries are the primary communication between hotels and customers, implying the customers' high expectation of receiving a response to their e-mail. Furthermore, due to the timeliness and significance of data offered by CRM technology, many hotels are utilizing CRM technology to enhance their service quality. Furthermore, Sirirak et al. (2011) contended that owing to increasing of competition and customer expectation in the hotel industry, hotels have adopted information and communication technology (ICT) as a way for dealing with rapidly changing environments.

It worth noting that literature revealed results regarding the impact of information technology on organization performance were inconsistent. Some of studies reveal non significant relationship between technology and hotel performance (Ham, Gon Kim \& Jeong, 2005; Karadag, Cobanoglu \& Dickinson, 2009; Law \& Au, 1998; Tavityaman, Qu \& Zhang, 2011). They argue that organizations have spent tremendous resources on information and computer technologies without achieving enhanced performance from all such expenditures. They further argued that organizations can not solely depend on information technology to improve their performance they must also concentrate on other organizational factors.

Contrarily, some studies revealed positive role of CRM technology on organization performance. Through its capability to collect, store, refine, analyze, and disseminate customer information within organization, CRM technology enables the organization to improve organization ability to attract and retain current and potential customers. Furthermore, without CRM technology, the role of many customer centric strategies would fail to achieve its goal (Akroush et al., 2011; Abdullateef, 2011; Sigala, 2005; Sin et al., 2005). Additionally, based on the resource based view theory, CRM technology can be considered as one of the important organization's resources that can be used to improve overall performance.

Specifically, previous studies contended that CRM technology has appositive and significant impact on financial performance and customer perspective (Alkrouch et al., 2011; Abdulattef, 2011). In this case, through increased use of information technology, hotels can increase their revenue and decrease the transactions cost, and as the 
potential of repeat business and consequently hotels' profitability will be increased (Chathoth, 2007)

Regarding to the impact of CRM technology on internal process and learning and growth dimensions, it is argued that, the effective use of information technology will improve productivity and service quality, as well as it will help in decreasing the potential for service errors and recovery costs associated with such errors (Chathoth, 2007; Olsen \& Connolly, 2000) Based on previous discussions, this study hypothesized that:

H1a: CRM technology has an effect on financial dimension of performance.

H1b: CRM technology has an effect on customer dimension of performance.

H1c: CRM technology has an effect on internal business process dimension of performance.

H1d: CRM technology has an effect on learning and growth dimension of performance.

\subsection{CRM Technology and Marketing Capabilities}

Marketing capabilities including planning and implementation are important because they give support to differentiation strategies by collecting relevant information from the market environment and developing marketing plans to act on the collected market related information (Kohli \& Jaworski, 1990; Morgan et al., 2003).

In this sense, building and management of customer relationships provides the essence of the marketing concept (Morgan and Hunt, 1994). Therefore, CRM allows organizations to develop more suitable marketing strategies and to carry out specific marketing activities efficiently and in a timely manner through the provision of superior front-line support and access to integrated customer data (Chen \& Popovich, 2003).

Thus, efficient and timely implementation of information technology can, no doubt, result to some benefits to hotel industry including enhanced service quality to meet customers' expectation, improved cost control, improved operational efficiency and effective marketing strategies (Cobanoglu, Corbachi \& Ryan, 2001; Law \& Jogaratnam, 2005; Piccoli, 2008). Conseqently, CRM technology can help service organizations such as the hotel industry to plan and implement successful marketing action to retain customer and make them more profitable based on customer data base and other systems that capture information over time (Roberts, Liu, \& Hazard, 2005). In addition, Chang et al. (2010) argued that CRM technology improves marketing capabilities by providing valuable customer information that help managers and employees to achieve specific marketing goals more effectively and efficiently. They contended that CRM technology has a positive influence on marketing capabilities (i.e. planning and implementation).

Based on foregoing discussions this study proposed the following hypotheses:

H2: CRM technology is significantly related to marketing planning capability

H3: CRM technology is significantly related to marketing implementation capability

\subsection{Marketing Capabilities and Organization Performance}

Marketing capability is considered as the firm's ability to utilize its resources for the performance of marketing activities that will result to satisfaction of customers' needs (Chang, 1996; Day, 1994). This type of capability is very important because it enables the understanding and accommodation of market needs (Srivastava, Fahey \& Christensen, 2001), and it cannot be acquired in the market, the organization has to create and develop it by itself (Krasnikov \& Jayachandran, 2008). Thus, marketing capability is a unique as its creation is based on knowledge, experience, skills and resources of the organization.

Vorhis, Morgan and Autry (2009) suggested two forms of marketing capabilities which include specialized marketing capabilities, and architectural marketing capabilities. Specialized marketing capabilities are characterized as task related marketing activities that involve marketing communications, personal selling, pricing, product development, and distribution. They are important in organizations because they help to emphasize differentiation-based product market strategy considering the fact that communication of benefits to both current and potential customers depends solely on them. Then, architectural capabilities are organizational capabilities focused on resource deployments in order to meet product-market goals. These capabilities help tremendously in the planning and coordination mechanisms necessary for effective performance of the marketing program-level activities toward achievement of the firm's over all strategies (Morgan et al., 2003). The next sections discuss the two types of architecture marketing capabilities (planning and implementation) in details.

\subsubsection{Marketing Planning Capability}

Marketing planning capability is defined as the firm's ability to expect and react to the changes in the market environment for the purpose of directing its resources and actions that result in the alignment of the firm with the 
environment (Slotegraaf \& Dickson, 2004). Similarly, Pulendran and Speed (1996) argued that planning marketing capabilities enable organization to recognize and implement goals including market orientation/customer orientation through defining the actions that must be taken. In addition, planning marketing capabilities can affect organization's activities regarding customer orientation.

Vorhies and Morgan (2005) have empirically found that marketing planning capabilities was positively related to organization performance, specifically improvement of organizational performance. In addition, marketing capabilities that are valuable, rare, non-replaceable, and inimitable are referred as sources of advantage that lead to superior performance of organization (Dutta, Zbaracki \& Bergen, 2003; Vorhies \& Morgan, 2005).

Consistent with presented arguments, this study proposes the following hypothesizes:

H4a: Marketing planning capability has a significant effect on financial performance

H4b: Marketing planning capability has a significant effect on customer performance

H4c: Marketing planning capability has a significant effect on internal business process performance

H4d: Marketing planning capability has a significant effect on learning and growth performance

\subsubsection{Marketing Implementation Capability}

Marketing implementation capability is defined as the process that changes plans into actions (Kotler \& Keller, 2005). In essence, marketing implementation capability measures the firm's ability to implement its strategy through organization and utilization of its marketing resources (Noble \& Mokwa, 1999; Vorhies \& Morgan, 2005). Similarly, marketing implementation capability is an organization's unique ability to transform resources into marketing plans and actions that are achievable (Eisenhardt \& Martin, 2000) and which results in positive performance.

In their empirical study, Vohies and Morgan (2005) revealed that marketing implementation capabilities were significantly related to organizational performance. It is believed that, marketing implementation capabilities is an important factor that influences marketing effectiveness in hotel organization that leads to enhanced hotel performance (Cizmar \& Weber, 2000). Consequently, many studies have demonstrated significant positive relationship between marketing implementation capabilities and organization performance (Vohies \& Morgan, 2005; White et al., 2003). Additionally, marketing implementation capabilities have been found to have direct significantly positive effect on organization performance in manufacturing and service organizations (Salter, Hult \& Olsen, 2010).

Based on aforementioned discussions, this study proposed the following hypothesis:

H5a: Marketing implementation capability has a significant effect on financial performance

H5b: Marketing implementation capability has a significant effect on customer performance

H5c: Marketing implementation capability has a significant effect on internal business process performance

H5d: Marketing implementation capability has a significant effect on learning and growth performance.

\subsection{CRM Technology, Marketing Capabilities, and Organizational Performance}

It is believed that CRM can play a vital role in developing marketing capabilities that lead to better organizational performance (Krasnikov et al., 2009). In other words, CRM antecedes the development of marketing capabilities in the organization, because marketing capability is an incorporated process that is designed to utilize the skills and resources, and corporate knowledge, and it enables businesses to better satisfy the needs of the customers through adding value services to their products (Azizi et al., 2009).

Furthermore, successful implementation of CRM needs cross-functional combination of processes, people, operations, and organization capabilities (Payne \& Frow, 2005). Also, Boulding et al. (2005) claimed that the success of CRM activities' hinges on how they have been aligned with the firm's existing capabilities. In this case, Chang et al. (2010) found that marketing capabilities play a mediating role between CRM technology and organizational performance.

In short, CRM technology enables organization to understand customers better, which is essential to plan marketing strategies and implement it successfully. Therefore, the current study hypothesizes that CRM technology indirectly influences organization performance by improving efficiency of marketing capabilities (planning and implementation), meaning that CRM positively influences a firm's marketing capabilities, leading to superior overall organization performance. Thus, the study proposed the following hypotheses:

H6a: Marketing planning capability mediates the relationship between CRM technology and financial 
performance

H6b: Marketing planning capability mediates the relationship between CRM technology and customer performance

H6c: Marketing planning capability mediates the relationship between CRM technology and internal process performance

H6d: Marketing planning capability mediates the relationship between CRM technology and learning and growth performance

H7a: Marketing implementation capability mediates the relationship between CRM technology and financial performance

H7b: Marketing implementation capability mediates the relationship between CRM technology and customer performance

H7c: Marketing implementation capability mediates the relationship between CRM technology and internal process performance

H7d: Marketing implementation capability mediates the relationship between CRM technology and learning and growth performance.

\section{Methodology}

\subsection{Research Framework}

The framework of the study is based on RBV theory which, states that an organization that has valuable resources and capabilities can effectively execute business strategy to achieve competitive advantage for organizational success. Figure 1 exhibits the framework this study. The study examines the relationship between CRM technology and hotel performance, and the mediating effects of planning and implementation (i.e. the marketing capabilities).

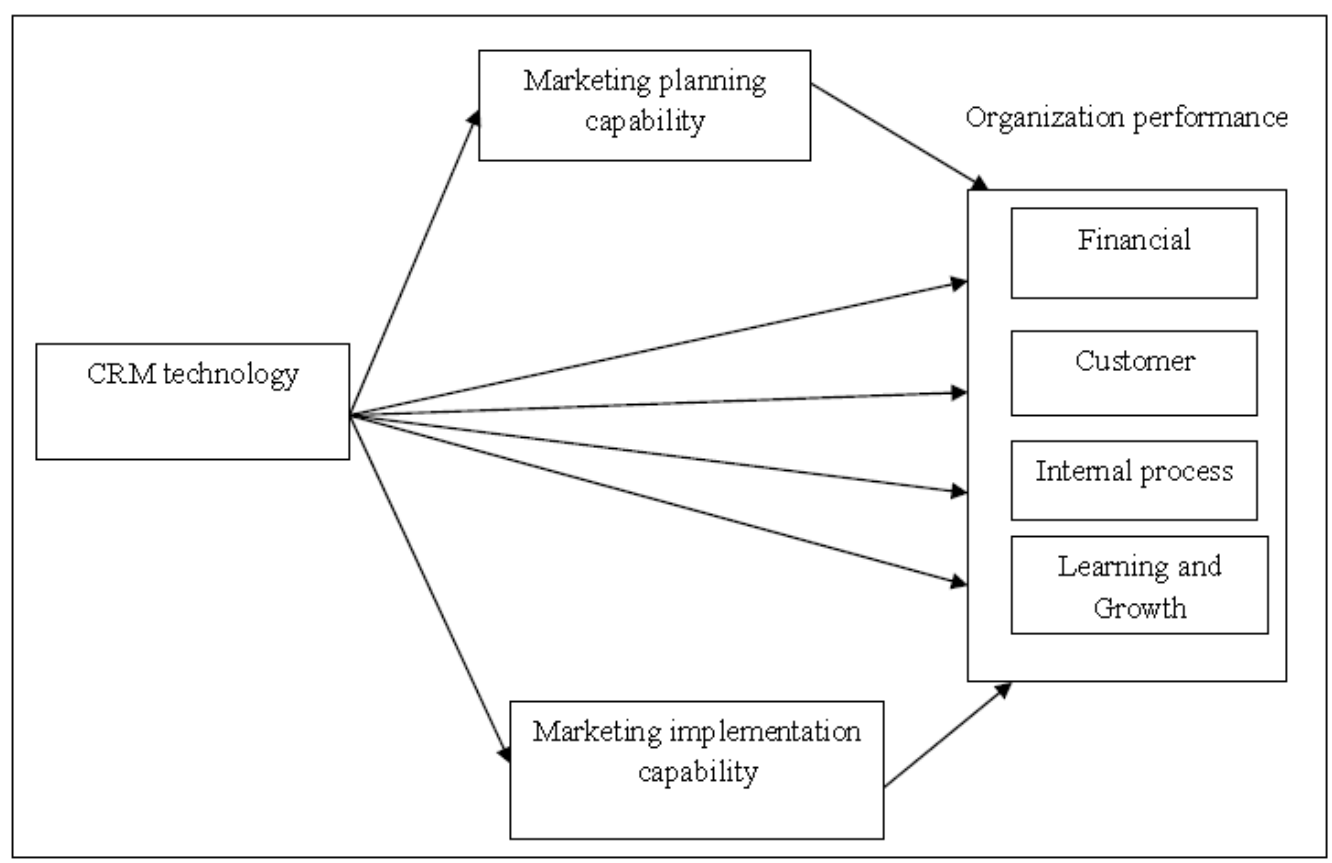

Figure 1. Research framework

\subsection{Measurement of Variables}

As far as this study is concerned CRM technology was operationalized utilizing the measurement developed by Sin et al. (2005) and Garrido-Moreno and Padilla-Melendez (2011). Marketing capabilities (planning and implementation) were opertionalized using the measurement developed by items from Morgan et al. (2003) and Vorhies \& Morgan (2005). Regarding to hotel performance, the current study employed the instrument that used 
by $\mathrm{Wu}$ and $\mathrm{Lu}$ (2012). All items were rated on a five -point Likert scales $(1=$ "Strongly disagree" and $5=$ "Strongly agree")

\subsection{Data Collection}

To test hypotheses for this study, we employed standardized questionnaire as the main instrument of data collection. The sample for this research comprised of employees selected from 3-5 star hotels operating in the Malaysian hotel industry. Specifically, the population of the study is drawn from the members in Malaysian Association Hotel (MAH). There were 447 members of 3 to 5 star hotels in the association. Questionnaires were mailed to general manager or senior manager for administration. General managers or senior managers of the selected hotels were mailed because they are widely believed to provide the best information regarding the business of hotels (Garrido-Moreno \& Padilla-Meléndez, 2011; Daghfous \& Barkhi, 2009; Wu \& Lu, 2012). A personalized cover letter and a pre-paid envelope accompanying each questionnaire explained the study purpose and assured confidentiality of the respondents. Furthermore, to encourage high response rate from participants, the researchers put letter from MAH requesting managers to fill the questionnaires. In addition, the researchers used 10 research assistants to help in distribution of the questionnaires.

Overall, a total of 164 questionnaires were collected and only 152 responses were accepted and used for further analysis.

\section{Data Analysis and Results}

Before the main analysis, both reliability and validity were determined. The study used Cronbach's alpha coefficient to test the reliability of instrument and the results revealed that the research instrument in term of reliability is within satisfactory level, since the scores of alpha coefficient of all variables were higher that 0.7 (Field, 2009; Pallant, 2007; Hair et al., 2010).

In terms of validity, exploratory factor analysis (EFA) used to test construct validity (Sekaran \& Bougie, 2010). Table 1 reveals the results of factor analysis and reliability test of all constructs.

Table 1. Factor loading and reliability test

\begin{tabular}{|c|c|c|c|}
\hline Factors and items & $\begin{array}{l}\text { Factor } \\
\text { loading }\end{array}$ & Eigen-values & Cronbach's $\alpha$ \\
\hline Technology based CRM & & 1.83 & .77 \\
\hline Organization has right hardware to serve its customers. & .70 & & \\
\hline Organization has right software to serve its customers. & .65 & & \\
\hline $\begin{array}{l}\text { Organization's information systems are integrated across the } \\
\text { different functional areas. }\end{array}$ & .69 & & \\
\hline $\begin{array}{l}\text { Individualized information about each customer is available at all } \\
\text { contact points. }\end{array}$ & .72 & & \\
\hline $\begin{array}{l}\text { Organization is able to consolidate all information acquired about } \\
\text { customers in comprehensive, centralized, up-to-date database. }\end{array}$ & .79 & & \\
\hline Marketing planning capability & & 3.04 & .84 \\
\hline My organization has superior marketing planning skills. & .78 & & \\
\hline My organization sets clear marketing goals. & .79 & & \\
\hline My organization develops creative marketing strategies. & .77 & & \\
\hline My organization segments and targets market effectively. & .73 & & \\
\hline My organization makes a thorough marketing planning process. & .82 & & \\
\hline Marketing implementation capability & & 2.70 & .79 \\
\hline $\begin{array}{l}\text { My organization allocates marketing resources to implement } \\
\text { marketing strategies effectively. }\end{array}$ & .69 & & \\
\hline My organization delivers marketing programs effectively. & .79 & & \\
\hline $\begin{array}{l}\text { My organization translates marketing strategies in to action } \\
\text { effectively. }\end{array}$ & .77 & & \\
\hline
\end{tabular}


My organization executes marketing strategies quickly. $\quad .70$

My organization monitors the performance of marketing strategies. $\quad .72$

Hotel performance: learning and growth perspective

Employees' ability to solve problems has improved.

The quality of employees' service has improved. $\quad .74$

The intention of employees to learn has improved. $\quad .82$

The corporate culture has promoted effectively. $\quad .85$

Internal Business perspective

The market share of hotel has increased.

$\begin{array}{ll}\text { The operating efficiency of hotel has increased. } & .94\end{array}$

Customer complaints have been decreased. $\quad .55$

The ability to retain old customers has improved. $\quad .72$

The ability to confirm target customers has improved. $\quad .44$

Customer perspective

The rate of sales growth has increased.

.86

The needs of various types of customers have satisfied.

Customer's repeat to purchase has increased $\quad .43$

Customer satisfaction has increased. $\quad .45$

Financial perspective

The total cost of hotel has decreased. $\quad .75$

The unexpected losses in hotel have reduced. $\quad 62$

The return on assets of hotel has increased. $\quad .72$

The net profit margin of hotel has increased. $\quad .50$

Furthermore, the Pearson moment correlation was also used to reveal the relationships among study's variables that includes CRM technology, marketing planning capability, marketing implementation capability, financial performance, customer performance, internal process and learning and growth performance. Table 2 indicated that there is a correlation among the various variables of this study. As well, the table indicated that all 21 coefficients are positive, thus demonstrating that the associations among CRM technology, marketing capabilities (planning and implementation) and hotel performance dimensions (financial, customer, internal process and learning and growth) is positive.

Table 2. Pearson correlations of study variables

\begin{tabular}{|c|c|c|c|c|c|c|c|}
\hline & 1 & 2 & 3 & 4 & 5 & 6 & 7 \\
\hline (1)Technology based CRM & 1 & & & & & & \\
\hline $\begin{array}{l}\text { (2)Marketing } \\
\text { capability }\end{array}$ & $0.43 * *$ & 1 & & & & & \\
\hline $\begin{array}{l}\text { (3)Marketing implementation } \\
\text { capability }\end{array}$ & $0.47 * *$ & $0.65^{* *}$ & 1 & & & & \\
\hline (4) Financial performance & $0.36^{* *}$ & $0.59^{* *}$ & $0.53^{* *}$ & 1 & & & \\
\hline (5) Customer performance & $0.38 * *$ & $0.63 * *$ & $0.73 * *$ & $0.56^{* *}$ & 1 & & \\
\hline (6) Internal process & $0.36^{* *}$ & $0.46^{* *}$ & $0.66^{* *}$ & $0.56^{* *}$ & $0.65^{* *}$ & 1 & \\
\hline (7) Learning and Growth & $0.30 * *$ & $0.56^{* *}$ & $0.57^{* *}$ & $0.46^{* *}$ & $0.60 * *$ & $0.60 * *$ & 1 \\
\hline
\end{tabular}

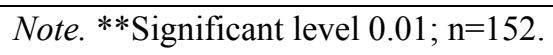


Although the model in this study shows as a path model, which may be estimated using Structural Equation Modelling (SEM) to test the hypothesis, regarding the sample size issue, multiple regression analysis is used in this study. Since there were 32 attributes in the survey questionnaire, a minimum sample size should be at least 320 for the requirement of SEM. A total of 152 responses were received at the end of the survey, which do not meet the recommended criteria of the statistical power of SEM by Kline (2011) and Stevens (2002). In this case, Field (2009) mentioned that a minimum sample size of regression with six or fewer predictors will be fine with a sample of 100. In the case of this study, simple regression analysis to examine the direct hypotheses was conducted. This technique used to test the relationship between single dependent variable and single independent variable (Hair et al., 2010; Field, 2009). Additionally hierarchical regression used to investigate the mediating impact of marketing capabilities on the relationship between CRM technology and various dimensions of organization performance. The standardized coefficient beta $(\beta)$ and $\mathrm{R}^{2}$ are used in explaining the regression results to indicate whether or not the formulated hypotheses are supported, as well as whether the predictor variable is considered to significantly predict the outcome variable if the $\mathrm{p}$ value is less than 0.05 . Table 3 has shown regression results of the relationship between CRM technology, marketing capabilities (planning and implementation) and the four dimensions of hotel performance.

Table 3. Summary of simple regression analysis for CRM technology influencing marketing planning capability, marketing implementation capability, financial, customer, internal process and learning and growth

\begin{tabular}{lllllll}
\hline Predictor & \multicolumn{7}{c}{ Criterion variables } \\
\hline CRM Technology & FP & CP & IP & LGP & MPC & MIC \\
\hline Coefficients $(\beta)$ & $0.35^{* *}$ & $0.38^{* *}$ & $0.36^{* * *}$ & $0.30^{* *}$ & $0.43^{* *}$ & $0.47^{* *}$ \\
$\mathrm{R}^{2}$ & 0.13 & 0.14 & 0.13 & 0.09 & 0.18 & 0.20 \\
$\mathrm{~F}$ & 21.44 & 25.05 & 22.52 & 14.56 & 33.27 & 37.47 \\
$N$ & \multicolumn{7}{c}{152} \\
\hline $\begin{array}{l}\text { Note. } \\
\text { financial performance, CP is customer performance, IP is internal business process and LGP is learning and } \\
\text { growth performance. }\end{array}$
\end{tabular}

Table 4 below also reveals the results of simple regression analysis of the relationship between marketing capabilities (planning and implementation) and various dimensions of hotel performance.

Table 4. Summary of simple regression analysis for marketing planning capability and marketing implementation capability influencing financial, customer, internal process and learning and growth

\begin{tabular}{|c|c|c|c|c|}
\hline & \multicolumn{4}{|c|}{ Criterion variables } \\
\hline & Financial & Customer & Internal process & Learning and growth \\
\hline & \multicolumn{4}{|c|}{ Coefficient $(\beta)$} \\
\hline \multicolumn{5}{|c|}{ Predictors } \\
\hline MPC & $0.59 * *$ & $0.63 * *$ & $0.55^{* *}$ & $0.56^{* *}$ \\
\hline $\mathrm{R}^{2}$ & 0.35 & 0.40 & 0.30 & 0.31 \\
\hline $\mathrm{F}$ & 79.10 & 66.06 & 63.37 & 66.90 \\
\hline MIC & $0.55^{* *}$ & $0.70^{* *}$ & $0.66^{* *}$ & $0.58 * *$ \\
\hline $\mathrm{R}^{2}$ & 0.30 & 0.49 & 0.44 & 0.33 \\
\hline $\mathrm{F}$ & 63.70 & 144.20 & 117.24 & 75.06 \\
\hline $\mathrm{N}$ & \multicolumn{4}{|c|}{152} \\
\hline
\end{tabular}

Additionally, using the Baron and Kenny's (1986) mediation technique, this study investigated the mediating 
impact of marketing capabilities (planning and implementation) on the relationship between CRM technology and various dimensions of performance. Tables 5 revealed results of hierarchical regression that demonstrated how marketing capabilities (marketing planning capability and marketing implementation capability) mediated the relationship between CRM technology and dimensions of performance (financial, customer, internal process, and learning and growth).

Table 5. Summary of Beta values on the relationship of mediation between CRM technology and, financial, customer, internal process, and learning and growth dimensions of hotel performance

\begin{tabular}{|c|c|c|c|c|c|c|c|c|c|c|c|c|}
\hline \multirow{2}{*}{ Predictor } & \multicolumn{12}{|c|}{ Criterion variables } \\
\hline & \multicolumn{3}{|l|}{ Financial } & \multicolumn{2}{|c|}{ Customer } & & \multicolumn{3}{|c|}{ Internal process } & \multicolumn{3}{|c|}{ Learning and Growth } \\
\hline & without & with & result & without & with & Result & without & With & result & without & with & Result \\
\hline CRM technology & $0.35 * *$ & & & $0.38^{* *}$ & & & $0.36^{* *}$ & & & $0.30^{* *}$ & & \\
\hline MPC & & 0.13 & $\mathrm{~F}$ & & 0.13 & $\mathrm{~F}$ & & $0.16^{*}$ & $P$ & & 0.07 & $\mathrm{~F}$ \\
\hline MIC & & 0.14 & $\mathrm{~F}$ & & 0.08 & $\mathrm{~F}$ & & 0.08 & $\mathrm{~F}$ & & 0.05 & F \\
\hline
\end{tabular}

Note. $* \mathrm{P}<0.05,{ }^{*} \mathrm{P}<0.01, \mathrm{MPC}=$ Marketing planning capability, $\mathrm{MIC}=$ Marketing implementation capability, $\mathrm{F}=$ Full mediator, $\mathrm{P}=$ Partial mediator.

The finding in table 3 indicated that the variation in financial, customer, internal process, and learning and growth performance as explained by CRM technology were $0.13,0.14,0.13$ and 0.09 respectively. Additionally, the results also showed that CRM technology positively related with hotel dimensions with $\beta$ values were 0.35 , $0.38,0.36$, and 0.30 respectively. Thus, the findings provided support for hypotheses H1a, H1b, H1c, and H1d.

Furthermore, results indicated that CRM technology has a positive and significant relationship with marketing capabilities (planning and implementation) with $\beta$ values of 0.43 and 0.47 respectively as well as, the results revealed that CRM technology explained 0.18 and 0.20 of variations of marketing planning capability and marketing implementation capability respectively. Thus, the results provided support to hypotheses $\mathrm{H} 2$ and $\mathrm{H} 3$.

Additionally, the results in Table 4 show that marketing planning capability has a positive impact on various dimensions of hotel performance (financial, customer, internal process, and learning and growth) with $\beta$ values $0.35,0.40,0.30$, and 0.31 respectively. Marketing planning capability also explained $0.59,0.63,0.55$, and 0.56 respectively of variations in hotel performance dimensions (financial, customer, internal process, and learning and growth). Consequently, the findings supported hypotheses $\mathrm{H} 4 \mathrm{a}, \mathrm{H} 4 \mathrm{~b}, \mathrm{H} 4 \mathrm{c}$, and H4d. The findings in table 4 also revealed that marketing implementation capability has a positive influence on various dimensions of hotel performance (financial, customer, internal process, and learning and growth) with $\beta$ values $0.55,0.70,0.66,0.58$ respectively, and marketing implementation capability explained $0.30,0.49,0.44$, and 0.33 of variation of various dimensions of hotel performance perceptively. Therefore, hypotheses H5a, H5b, H5c, and H5d are supported.

Regarding to the mediating role of marketing planning capability on the relationship between CRM technology and various dimensions of performance, results as indicated in table 5 revealed that CRM technology influenced hotel performance dimensions in step 1 and step 2 upon the introduction of marketing planning capability (mediating variable). The beta coefficient for the direct path (step 1) between CRM technology and hotel performance dimensions (i.e. financial, customer, internal process and learning and growth) were $0.35,0.38$, 0.36 , and 0.30 respectively. When marketing planning capability was included as a mediator ( step 2), the beta coefficient for CRM technology dropped to $0.13,0.13,0.16$, and 0.07 respectively, showing that mediation does exist in the relationship, but the relationship became non significant between CRM technology and three dimensions of hotel performance (i.e. financial, customer and learning and growth). On the other hand, the relationship between CRM technology and internal process still significant when marketing planning capability was included.

Specifically, the results demonstrated that marketing planning capability fully mediates the relationship between CRM technology and hotel performance dimensions (i.e. financial, customer and learning and growth), but partially mediates the relationship between CRM technology and internal process dimension of hotel performance. This implied that CRM technology indirectly influences hotel performance through marketing 
planning capability, thus, providing empirical support to hypotheses H6a, H6b, H6c, and H6d.

A similar mediation procedure was carried out to investigate the influence of marketing implementation capability on the relationship between CRM technology and various dimensions of hotel performance. Table 5 also showed that CRM technology influenced hotel performance dimensions in step 1 and step 2 upon the introduction of marketing implementation capability (i.e. the mediating variable). The beta coefficient for the direct path (step 1) between CRM technology and hotel performance dimensions (i.e. financial, customer, internal process and learning and growth) were $0.35,0.38,0.36$, and 0.30 respectively. When marketing implementation capability was included as a mediator (step2), the Beta coefficient for CRM technology dropped to $0.14,0.08,0.08$, and.05 respectively, revealing that mediation does exist in the relationship, but when marketing implementation capability was included the relationships between CRM technology and the four dimensions of hotel performance, the relationships became non-significant.

Therefore, it could be interpreted that marketing implementation capability fully mediates the relationship between CRM technology and hotel performance dimensions (i.e. financial, customer, internal process and learning and growth). Specifically, the results indicated that CRM technology indirectly influences hotel performance through marketing implementation capability, providing support for hypotheses $\mathrm{H7a}, \mathrm{H} 7 \mathrm{~b}, \mathrm{H} 7 \mathrm{c}$, and $\mathrm{H} 7 \mathrm{~d}$.

\section{Discussion}

From the results presented in previous sections, it is clear that the current findings are consistent with the resource-based perspective theory, which emphasizes the special role of internal and organizational aspects as determinants of the firm's success. Thus according to this theoretical approach, the efficiency and success of firms are a function of their abilities, competences, and skills in developing and managing resources that assist the creation of sustainable competitive advantage (Barney, 1991; Grant, 1991). In the present study, the results demonstrated that only when the CRM technology resources are integrated into the marketing capabilities (planning and implementation) in organization, will the firm be able to create an organizational capability in CRM that is difficult to imitate and replicate, thus becoming a source of sustainable competitive advantage.

Generally, the present study revealed that CRM technology has a significant and positive relationship with the four dimensions of performance, namely: financial $(\beta=0.35)$, customer $(\beta=0.38)$, internal processes $(\beta=0.36)$ and learning and growth $(\beta=0.30)$. CRM technology also explained $0.35,0.38,0.36$, and 0.30 respectively of variation in dimensions of hotel performance (financial, customer, internal process, and learning and growth). Thus, the present study is in line with previous CRM studies (Akroush et al., 2011; Dutu \& Halmajan, 2011; Kasim \& Minai, 2009), which demonstrated that CRM technology plays a vital role in improving business performance. Furthermore, current finding is consistent with findings of Camisón (2000) and Tavitiyaman et al. (2011). Camisón (2000) stated that information technology creates added value within the hotel firm. Similarly, Tavitiyaman et al. (2011) argue that effective information technology brings convenience to both employees and customers in hotel sector.

Hence, the hardware and software of CRM technology can asset organizations to serve its customers in an effective manner and consequently improves customer satisfaction, loyalty and retention, which in turn can lead to improve financial performance of organization (Alkrouch et al., 2011). In this respect, CRM technology can enable hotels to incorporate the related information on each customer within the enterprise in order to smooth the progress of more effective planning, marketing and services, which in turn it helps to create a competitive advantage in the market through providing a unique product and service that satisfy special needs of their customer.

Additionally, the finding indicates there is a positive and significant relationship between CRM technology and marketing planning capability $(\beta=0.18 ; \mathrm{p}<0.01)$ and marketing implementation capability $(\beta=0.20 ; \mathrm{p}<0.01)$. Previous studies (Cobanoglu, Corbachi, \& Ryan, 2001; Law \& Jogaratnam, 2005; Piccoli, 2008) were supportive of the present finding. They indicated that efficient and timely implementation of information technology does provide a lot of benefits to hotels including improved cost control, improved operational efficiency, enhanced service quality to meet customers' expectation, and effective marketing strategies. Moreover, the current study also supported findings of previous studies (Chang et al., 2010; Roberts et al., 2005) that contended that CRM technology enables organization to plan and implement successful marketing action to retain customer and make them more profitable based on customer database and other systems that capture information over. In line with this, Chang et al. (2010) stated that, CRM technology improves marketing capabilities by providing valuable customer information that help managers and employees to accomplish specific marketing goals more effectively and efficiently. 
The findings also contended that marketing planning capability and marketing implementation capability have a positive and significant relationship with various dimensions of hotel performance. These findings are in line with previous studies (Chang et al., 2010; Krasnikov \& Jayachandran, 2008; Vorhies \& Morgan, 2005) that mentioned that firms with better marketing capabilities generally have higher business performance. This positive and significant relationship between marketing capabilities(planning and implementation) because an effective marketing planning and implementation including superior marketing skills, clear marketing goals , allocation of resources to implement marketing strategies, implementing marketing effectively and efficiency, and monitor of marketing strategies performance is expected to produce high service quality, increase customer satisfaction and retention and consequently higher sales and profits.

Regarding mediation results, the present study revealed the mediating impact of marketing capabilities (planning and implementation) on the relationship between CRM technology and hotel performance dimensions. The finding also show that the two mediators (marketing planning capability and marketing implementation capability) approximately have the same influence on the relationship between CRM technology and various dimensions of hotel performance. Therefore, hotel's manager must pay more attention to both of them in order to implement CRM technology successfully and improve their performance accordingly. These results supported the previous findings of Chang et al. (2010) who tested the mediating effect of marketing capability on the relationship between CRM technology and organization performance. Additionally the results supported the argument made by Krasnikov et al. (2009) who stated that successful implementation of CRM technology can play a key role in developing marketing capabilities, which lead to better organizational performance.

\section{Implications of the Study}

This study has several implications, which were discussed in line theoretical and practical contributions.

From theoretical perspective, the study filled the literature gap by investigating the direct influence of CRM technology on various dimensions of hotel performance (Wu \& Lu, 2012). Directly connected to this were the conflicting results between CRM technology use and performance, which suggested testing for mechanism and the conditions by which CRM technology successfully enhances business effectiveness (Boulding et al., 2005; Ernst et al., 2011; Jayachandran et al., 2005). Therefore, the current study examined the mediating role of marketing planning capability and marketing implementation capability separately on the relationship between CRM technology and various dimensions of hotel performance in order to reveal which marketing capability is more strongly related to CRM technology (Chang et al., 2010). Specifically, this study demonstrated that hotels' use of CRM technology is related to improved marketing capabilities (planning and implementation), which in turn enhance various dimensions of hotels' performances (i.e. financial, customer, internal process, and learning and growth).

From aspect of practical contribution, this study has provided an insight on the hotel's performance in Malaysia from the perspective of CRM technology and marketing capabilities. The study demonstrated that hotel managers should adopt new information technology to assist hotel employees serve customers better and thus improving financial performance. CRM technology can be used as an operational tool for business internal quality control because it can transmit important customers' data to where they are needed (i.e., customer service centers). Hence, technology elevates competitive advantage; it can support employees and enhance their capacity to offer superior service to customers.

Furthermore, hotels need to give much attention to their marketing capabilities (planning and implementation) because of their significant positive effects on performance. Hotel managers must focus on improving the skills of their employees, motivating them to be creative, and allocating all needed resources that can help them to achieve their marketing goals, which it also can enhance the impact of CRM technology and consequently improving their performance.

\section{Conclusion and Future Studies}

Conclusively, this research has contributed both theoretically and managerially. This study examined the holistic process by which CRM technology leads to organizational performance, thus providing a knowledge base for organizations to know what it should do in order to actualize CRM technology performance. This study has succeeded in providing evidence that marketing capabilities (planning and implementation) play a crucial role in translating CRM technology into various dimensions of business performance (financial, customer, internal process and learning and growth). This study demonstrated that CRM technology is important determinant of hotel performance dimensions. Thus, hotel managers can pay attention to marketing capabilities (planning and implementation) in hotels to get benefits from CRM technology and consequently create competitive advantage to improve their performance. 
Despite the significant contributions made by this study, this study has some limitations. Future studies should strive to overcome to the limitations. First, because this research only examined a few variables for enhancing performance of a hotel industry, future research should investigate the possibility of mediating or moderating effects of external environmental factors and hotel attributes on the relationship between CRM technology and hotel performance. Second, because this study focused specifically on the Malaysian hotel sector, the results obtained may not be used for generalization to other sectors of the economy or other countries. Therefore, future studies should try to replicate this model in other segments of Malaysian service sector. As well, future research may be conducted other countries, in order to improve its validity and increase its generalizability. Third, this study used managerial perceptions to evaluate different variables of the study, as such future studies should investigate perceptions of the various parties involved in developing CRM including managers, employees, and customers. In addition, future research may use objective data (i.e. financial data) to evaluate the influence of CRM technology on organization performance, thus providing a different perspective to address the research problem.

\section{References}

Abdullateef, A. O. (2011). The impact of customer relationship management on caller satisfaction in customer contact centers: Evidence from Malaysia. Unpublished $\mathrm{PhD}$ thesis, UUM, Malaysia.

Akroush, M. N., Dahiyat, S. E., Gharaibeh, H. S., \& Abu-Lail, B. N. (2011). Customer relationship management implementation: an investigation of a scale's generalizability and its relationship with business performance in a developing country context. International Journal of Commerce and Management, 21(2), 158-190. http://dx.doi.org/10.1108/10569211111144355

Azizi, S., Movahed, S. A., \& Khah, M. H. (2009). The effect of marketing strategy and marketing capability on business performance. Case study: Iran's medical equipment sector. Journal of Medical Marketing: Device, Diagnostic and Pharmaceutical Marketing, 9(4), 309-317. http://dx.doi.org/10.1057/jmm.2009.33

Barney, J. B. (1991). Firm Resources and Sustained Competitive Advantage. Journal of Management, 17(1), 99-120. http://dx.doi.org/10.1177/014920639101700108

Baron, R. M., \& Kenny, D. A. (1986). The moderator-mediator variable distinction in social psychological research: Conceptual, strategic, and statistical considerations. Journal of personality and social psychology, 51(6), 1173-1182. http://dx.doi.org/10.1037/0022-3514.51.6.1173

Boulding, W., Staelin, R., Ehret, M., \& Johnston, W. J. (2005). A customer relationship management roadmap: What is known, potential pitfalls, and where to go. Journal of Marketing, 155-166. http://dx.doi.org/10.1509/jmkg.2005.69.4.155

Camisón, C. (2000). Strategic attitudes and information technologies in the hospitality business: An empirical

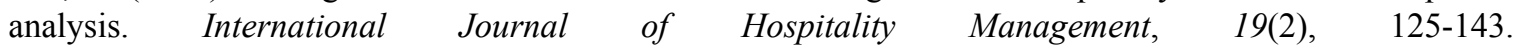
http://dx.doi.org/10.1016/S0278-4319(99)00059-6

Chang, T. L. (1996). Cultivating global experience curve advantage on technology and marketing capabilities. International Marketing Review, 13(6), 22-42. http://dx.doi.org/10.1108/02651339610151908

Chang, W., Park, J. E., \& Chaiy, S. (2010). How does CRM technology transform into organizational performance? A mediating role of marketing capability. Journal of Business Research, 63(8), 849-855. http://dx.doi.org/10.1016/j.jbusres.2009.07.003

Chathoth, P. K. (2007). The impact of information technology on hotel operations, service management and transaction costs: A conceptual framework for full-service hotel firms. International Journal of Hospitality Management, 26(2), 395-408. http://dx.doi.org/10.1016/j.ijhm.2006.03.004

Chen, I. J., \& Popovich, K. (2003). Understanding customer relationship management (CRM): People, process and technology. Business Process Management Journal, 9(5), 672-688. http://dx.doi.org/10.1108/14637150310496758

Cizmar, S., \& Weber, S. (2000). Marketing effectiveness of the hotel industry in Croatia. International Journal of Hospitality Management, 19(3), 227-240. http://dx.doi.org/10.1016/S0278-4319(00)00020-7

Cobanoglu, C., Corbachi, K., \& Ryan, B. (2001). A comparative study: The impact of technology in lodging properties in the United States and Turkey. International Journal of Hospitality Information Technology, 2(1), 23-40. http://dx.doi.org/10.3727/153373401803617774

Day, G. S. (1994). The capabilities of market-driven organizations. The Journal of Marketing, 37-52. http://dx.doi.org/10.2307/1251915 
Dev, C. S., \& Olsen, M. D. (2000). Marketing challenges for the next decade. Cornell Hotel and Restaurant Administration Quarterly, 41(1), 41-47. http://dx.doi.org/10.1177/001088040004100122

Dutta, S., Zbaracki, M. J., \& Bergen, M. (2003). Pricing process as a capability: A resource-based perspective. Strategic Management Journal, 24(7), 615-630. http://dx.doi.org/10.1002/smj.323

Dutu, C., \& Hălmăjan, H. (2011). The effect of organizational readiness on CRM and business performance. International journal of computers, 1(2), 106-114.

Eisenhardt, K. M., \& Martin, J. A. (2000). Dynamic capabilities: What are they? Strategic Management Journal, 21(10-11), 1105-1121. http://dx.doi.org/10.1002/1097-0266(200010/11)21:10/11<1105::AID-SMJ133> 3.0.CO;2-E

Ernst, H., Hoyer, M., Krafft, M., \& Krieger, K. (2011). Customer relationship management and company performance - The mediating role of new product performance. Journal of the Academic Marketing Science, 39(2), 290-306. http://dx.doi.org/10.1007/s11747-010-0194-5

Fan, Y. W., \& Ku, E. (2010). Customer focus, service process fit and customer relationship management profitability: The effect of knowledge sharing. The Service Industries Journal, 30(2), 203-223. http://dx.doi.org/10.1080/02642060802120141

Field, A. (2009). Discovering statistics using SPSS for Windows. London: Saga Publication

Garrido-Moreno, A., \& Padilla-Meléndez, A. (2011). Analyzing the impact of knowledge management on CRM success: The mediating effects of organizational factors. International Journal of Information Management, 31(5), 437-444. http://dx.doi.org/10.1016/j.ijinfomgt.2011.01.002

Grant, R. M. (1991). The resource-based theory of competitive advantage: Implications for strategy formulation. Califomia Management Review, 33(3), 114-135. http://dx.doi.org/10.2307/41166664

Greenberg, P. (2001). CRM at the speed of light: Capturing and keeping customers in internet real time. Osborne/McGraw-Hill.

Hair, J. F., Black, W. C., Babin, B. J., Anderson, R. E., \& Tatham, R. L. (2010). Multivariate data analysis a global perspective (7th ed.). U.S.A: Upper Saddle River.

Ham, S., Gon Kim, W., \& Jeong, S. (2005). Effect of information technology on performance in upscale hotels. International Journal of Hospitality Management, 24(2), 281-294. http://dx.doi.org/10.1016/j.ijhm.2004.06.010

Jayachandran, S., Sharma, S., Kaufman, P., \& Raman, P. (2005). The role of relational information processes and technology use in customer relationship management. Journal of Marketing, 69(4), 177-192. http://dx.doi.org/10.1509/jmkg.2005.69.4.177

Kaplan, R. S., \& Norton, D. P. (1992, January-February). The balanced scorecard: Measures that drive performance. Harvard Business Review, 71-79.

Karadag, E., Cobanoglu, C., \& Dickinson, C. (2009). The characteristics of IT investment decisions and method used in the US lodging industry. International Journal of Contemporary Hospitality Management, 21(1), 52-68. http://dx.doi.org/10.1108/09596110910930188

Kasim, A., \& Minai, B. (2009). Linking CRM strategy, customer performance measure and performance in hotel industry. International Journal of Economics and Management, 3(2), 297-316.

Kline, R. B. (2011). Principles and Practice of Structural Equation Modeling (3rd ed.). Guilford Press, New York.

Kohli, A. K., Jaworski, B. J., \& Kumar, A. (1993, November). MARKOR: A measure of market orientation. Journal of Marketing Research, 30, 467-477. http://dx.doi.org/10.2307/3172691

Kotler, P. (2002). When to use CRM and When to forget it! Paper presented at the Academy of Marketing Science, Sanibel Harbour Resort and Spa, 30 May.

Kotler, P., \& Keller, K. L. (2006). Marketing Management (12th ed.). New Jersey: Pearson International Edition.

Krasnikov, A., \& Jayachandran, S. (2008). The relative impact of marketing, research-and-development, and operations capabilities on firm performance. Journal of Marketing, 72(4), 1-11. http://dx.doi.org/10.1509/jmkg.72.4.1

Krasnikov, A., Jayachandran, S., \& Kumar, V. (2009). The impact of customer relationship management implementation on cost and profit efficiencies: Evidence from the US commercial banking industry. Journal 
of Marketing, 73(6), 61-76. http://dx.doi.org/10.1509/jmkg.73.6.61

Law, R., \& Au, N. (1998). Information technology applications to the Hong Kong hotel industry. International Journal of Management, 15(3), 377-384.

Law, R., \& Jogaratnam, G. (2005). A study of hotel information technology applications. International Journal of Contemperary Hospitality Management, 17(2), 170-180. http://dx.doi.org/10.1108/09596110510582369

Law, R., Leung, R., \& Buhalis, D. (2009). Information technology applications in hospitality and tourism: A review of publications from 2005 to 2007. Journal of Travel \& Tourism Marketing, 26(5-6), 599-623. http://dx.doi.org/10.1080/10548400903163160

Line, N. D., \& Runyan, R. C. (2012). Hospitality marketing research: Recent trends and future directions. International Journal of Hospitality Management, $31(2), \quad$ 477-488. http://dx.doi.org/10.1016/j.ijhm.2011.07.006

Minghetti, V. (2003). Building customer value in the hospitality industry: Towards the definition of a customer-centric. Journal of Information Technology \& Tourism, 6(2), 141-152. http://dx.doi.org/10.3727/109830503773048246

Morgan, N. A., Zou, S., Vorhies, D. W., \& Katsikeas, C. S. (2003). Experiential and informational knowledge, architectural marketing capabilities, and the adaptive performance of export ventures. Decision Sciences, 34(2), 287-321. http://dx.doi.org/10.1111/1540-5915.02375

Morgan, R. M., \& Hunt S. D. (1994). The commitment-trust theory of relationship marketing. Journal of Marketing, 58(3), 20-38. http://dx.doi.org/10.2307/1252308

Moriarty, J., Jones, R., Rowley, J., \& Kupiec-Teahan, B. (2008). Marketing in small hotels: A qualitative study. Marketing Intelligence \& Planning, 26(3), 293-315. http://dx.doi.org/10.1108/02634500810871348

Mukerjee, K., \& Singh, K. (2009). CRM: A strategic approach. ICFAI. Journal of Management Research, 8(2), 65-82.

Noble, C. H., \& Mokwa, M. P. (1999). Implementing marketing strategies: Developing and testing a managerial theory. Journal of Marketing, 63(4), 57-73. http://dx.doi.org/10.2307/1251974

Olsen, M. D., \& Connolly, D. J. (2000). Experience-based travel. Cornell Hotel and Restaurant Administration Quarterly, 4l(1), 30-40. http://dx.doi.org/10.1177/001088040004100121

Payne, A., \& Frow, P. (2005). A strategic framework for customer relationship management. Journal of Marketing, 69(4), 167-176. http://dx.doi.org/10.1509/jmkg.2005.69.4.167

Piccoli, G. (2008). Information technology in hotel management: A framework for evaluating the sustainability of it-dependent competitive advantage. Cornell Hospitality Quarterly, 49(3), 282-296. http://dx.doi.org/10.1177/1938965508320722

Piccoli, G., O’Connor, P., Capaccioli, C., \& Alvarez, R. (2003). Customer relationship management - a driver for change in the structure of the U.S. lodging industry. Cornell Hotel and Restaurant Administration Quarterly, 44(4), 61-73.

Pulendran, S., \& Speed, R. (1996). Planning and doing: The relationship between marketing planning styles and market orientation. Journal of Marketing Management, 12(1-3), 53-68. http://dx.doi.org/10.1080/0267257X.1996.9964400

Randolph, W. A., \& Dess, G. G. (1984). The congruence of perspective of organizational design: A conceptual model and multivariate research approach. Academy of Marketing Review, 9(1), 114-127.

Reimann, M., Schilke, O., \& Thomas, J. S. (2010). Customer relationship management and firm performance: The mediating role of business strategy. Journal of the Academy of Marketing Science, 38(3), 326-346. http://dx.doi.org/10.1007/s11747-009-0164-y

Rigby, D. K., Reichheld, F. F., \& Schefter, P. (2002). Avoid the four perils of CRM. Harvard Business Review, 80(2), 101-109.

Roberts, M. L., Liu, R. R., \& Hazard, K. (2005). Strategy, technology and organisational alignment: Key components of CRM success. The Journal of Database Marketing \& Customer Strategy Management, 12(4), 315-326. http://dx.doi.org/10.1057/palgrave.dbm.3240268

Ryals, L. J., (2005). Making customer relationship management work: The measurement and profitable management of customer relationships. Journal of Marketing, 69(4), 252-261. 
http://dx.doi.org/10.1509/jmkg.2005.69.4.252

Salter, F. S., Hult, M. T. G., \& Olsen, M. E. (2010), Factors influencing the relative importance of marketing strategy creativity and marketing strategy implementation effectiveness. Industrial Marketing Management, 39, 551-559. http://dx.doi.org/10.1016/j.indmarman.2008.03.007

Sekaran, U., \& Bougie, R. (2010). Research Methods for Business: A Skill Building Approach (5th ed.). New Delhi: Wiley India.

Sigala, M. (2005). Integrating customer relationship management in hotel operations: Managerial and operational implications. International Journal of Hospitality Management, 24(3), 391-413. http://dx.doi.org/10.1016/j.ijhm.2004.08.008

Sin, L. Y., Alan, C. B., \& Yim, F. H. (2005). CRM: Conceptualization and scale development. European Journal of Marketing, 39(11-12), 1264-1290. http://dx.doi.org/10.1108/03090560510623253

Sirirak, S., Islam, N., \& Khang, B. D. (2011). Does ICT adoption enhance hotel performance? Journal of Hospitality and Tourism Technology, 2(1), 34-49. http://dx.doi.org/10.1108/17579881111112403

Slotegraaf, R. J., \& Dickson, P. R. (2004). The paradox of a marketing planning capability. Journal of the Academy of Marketing Science, 32(4), 371-385. http://dx.doi.org/10.1177/0092070304265217

Srivastava, R. K., Fahey, L., \& Christensen, H. K. (2001). The resource-based view and marketing: the role of market- based assets in gaining competitive advantage. Journal of Management, 27(6), 777-802. http://dx.doi.org/10.1177/014920630102700610

Stevens, J. P. (2002). Applied Multivariate Statistics for the Social Sciences (4th ed.). Lawrence Erlbaum Associates, New Jersey.

Tavitiyaman, P., Qu, H., \& Zhang, H. Q. (2011). The impact of industry force factors on resource competitive strategies and hotel performance. International Journal of Hospitality Management, 30(3), 648-657. http://dx.doi.org/10.1016/j.ijhm.2010.11.010

Tourism Malaysia. (2013). Tourism Malaysia-Statstics. Retrieved April 26, 2013, from http://corporate.tourism.gov.my/research.asp?page=facts_figures

Vorhies, D. W., \& Morgan, N. A. (2005). Benchmarking Marketing Capabilities for Sustainable Competitive Advantage. Journal of Marketing, 69(1), 80-94. http://dx.doi.org/10.1509/jmkg.69.1.80.55505

Vorhies, D. W., Morgan, R. E., \& Autry, C. W. (2009). Product-market strategy and the marketing capabilities of the firm: Impact on market effectiveness and cash flow performance. Strategic Management Journal, 30(12), 1310-1334. http://dx.doi.org/10.1002/smj.798

White, J. C., Contant, J. S., \& Echambadi, R. (2003). Marketing Strategy Development Styles, Implementation Capability, and Firm Performance: Investigating the Curvilinear Impact of Multiple Strategy-Making Styles. Marketing Letters, 14(2), 111-124. http://dx.doi.org/10.1023/A:1025415018239

Wu, S. I., \& Hung, J. M. (2007). The performance measurement of cause-related marketing by balance scorecard. Total Quality Management, 18(7), 771-791. http://dx.doi.org/10.1080/14783360701349831

Wu, S. I., \& Lu, C. L. (2012). The relationship between CRM, RM, and business performance: A study of the hotel industry in Taiwan. International Journal of Hospitality Management, 31(1), 276-285. http://dx.doi.org/10.1016/j.ijhm.2011.06.012

Yen, F. L., \& Othman, M. (2011). Data Envelopment Analysis to Measure Efficiency of Hotels in Malaysia. SEGi Review, 4(1), 25-36.

Yim, F. H. K., Anderson, R. E., \& Swaminathan, S. (2004). Customer relationship management: Its dimensions and effect on customer outcomes. Journal of Personal Selling and Sales Management, 24(4), 263-278.

Yoo, M., Lee, S., \& Bai, B. (2011). Hospitality marketing research from 2000 to 2009: Topics, methods, and trends. International Journal of Contemporary Hospitality Management, 23(4), 517-532. http://dx.doi.org/10.1108/09596111111130010

\section{Copyrights}

Copyright for this article is retained by the author(s), with first publication rights granted to the journal.

This is an open-access article distributed under the terms and conditions of the Creative Commons Attribution license (http://creativecommons.org/licenses/by/3.0/). 